\title{
Pengolahan Air Sumur Bor Menggunakan Adsorben Fly-ash/ Zeolit dan Ultrafiltrasi
}

\author{
Subriyer Nasir ${ }^{1}$, Atikah Damayantiㄹ, Rizki Nugraha ${ }^{1}$, Roma Dhona Indra Putra ${ }^{1}$, Agung \\ Prabowo ${ }^{1}$, dan Helmi Hakki²
}

1Jurusan Teknik Kimia Fakultas Teknik Universitas Sriwijaya; e-mail: subriyer@unsri.ac.id

${ }_{2}^{2}$ Jurusan Teknik Sipil dan Perencanaan, Fakultas Teknik Universitas Sriwijaya

\begin{abstract}
ABSTRAK
Penelitian ini bertujuan untuk memanfaatkan adsorben sebagai pengolahan awal sebelum proses ultrafiltrasi untuk pengolahan air sumur bor menjadi air layak konsumsi. Air umpan yang digunakan berasal dari sumur bor yang berada di areal Fakultas Teknik Universitas Sriwijaya Indralaya. Dua jenis adsorben yang digunakan adalah fly-ash dan zeolit dengan ukuran partikel masing-masing 20 mesh. Masing-masing adsorben ditempatkan dalam tabung FRP (Fiberglass Reinforced Plastic) yang dikombinasikan dengan membran UF (ultrafiltrasi) komersial tipe HM90UF (50,000-150000 Dalton). Variabel proses yang diteliti adalah waktu operasi mulai dari 15 sampai 90 menit laju alir air umpan menuju membran ultrafiltrasi yang diatur dari 4, 6 dan 8 L/menit. Parameter kualitas air yang menjadi fokus adalah pH, turbiditi, kadar nitrat, besi, dan mangan serta bakteri e-coli dan coliform. Pengukuran parameter analisis air dilakukan menurut Standar Nasional Indonesia (SNI), kandungan bakteri menurut metode APHA dan kadar ion logam menggunakan AAS (atomic absorption spectroscopy). Hasil yang diperoleh menunjukan bahwa kombinasi fly-ash dan ultrafiltrasi dapat meningkatkan $\mathrm{pH}$ air sumur bor dari 5,43 menjadi 7,0-8,1 dengan persentase penurunan turbiditi mencapai 99,48\% sedangkan kombinasi zeolit dengan ultrafiltrasi dapat meningkatkan pH sampel menjadi 7,1 sampai 7,3 dengan penurunan turbiditi sebesar 99,71\%. Air yang dihasilkan memenuhi syarat air bersih bahkan air minum karena bebas bakteri e-coli dan coliform. Penggunaan adsorben sebelum membran ultrafiltrasi dapat meningkatkan kualitas air sumur bor sehingga menjadi memenuhi syarat air bersih.
\end{abstract}

Kata kunci: Adsorpsi, Sumur bor, Fly-ash, Zeolit, Ultrafiltrasi

\begin{abstract}
This research is aimed to the use of adsorbents as pre-treatment prior to the ultrafiltration process for the treatment of well water from Enginering Faculty of Universitas Sriwijaya into consumable water. Two types of adsorbents used were fly-ash and zeolite. The adsorbents with particle size of 20 mesh were placed in the Fiberglass Reinforced Plastic (FRP) tube combined with a commercial ultrafiltration (UF) membrane (50,000-150000 Dalton). The process variables studied were operating time (15 to $90 \mathrm{~min}$.) and feed water flow rate $(4,6,8 \mathrm{~L} / \mathrm{min}$.) to the ultrafiltration membrane. Water quality parameters examined were $\mathrm{pH}$, turbidity, nitrate, iron, and manganese concentration as well as e-coli and coliform bacteria. Measurement of water analysis parameters is carried out according to SNI (the Indonesian National Standard), bacterial content according to the APHA method and metal ion content using AAS (atomic absorption spectroscopy). Results showed that combined fly-ash and UF can increase the $\mathrm{pH}$ of water from 5.43 to 7.0-8.1 with the turbidity removal of $99.48 \%$ while combined of zeolite and UF can increase the $\mathrm{pH}$ to 7.1 to 7.23 and $99.71 \%$ of turbidity removal. The use of adsorbents prior to ultrafiltration membranes can improve the water quality and met the clean water standard.
\end{abstract}

Keywords: Adsorption, well water, Fly-ash, Zeolite, Ultrafiltration

Citation: Nasir, S., A. Damayanti, R, Nugraha., R.D.I. Putra., A. Prabowo., dan H. Hakki., (2020). Pengolahan Air Sumur Bor Menggunakan Adsorben Fly-ash/Zeolit dan Ultrafiltrasi. Jurnal Ilmu Lingkungan, 18(1), 193-199, doi:10.14710/jil.18.1.193-199

\section{Pendahuluan}

Universitas Sriwijaya (Unsri) memiliki dua kampus yaitu di kota Palembang dan Indralaya Kabupaten Ogan Ilir. Kampus Unsri di kabupaten Ogan Ilir memiliki areal sekitar 720 ha dan sejak tahun 1993 memiliki instalasi pengolahan air bersih dengan kapasitas terpasang 20L/detik dengan bahan baku berasal dari sungai Kelekar (Nasir, 2013).
Suplai air yang rata-rata $700 \mathrm{~m}^{3}$ /hari dirasakan tidak mencukupi terutama pada saat aktivitas kampus yang padat seperti pelaksanaan praktikum di laboratorium, penerimaan mahasiswa baru, yudisium dan wisuda serta kegiatan lain yang melibatkan civitas akademika dalam jumlah yang besar. Suplai air juga menjadi berkurang ketika musim kemarau karena permukaan air sungai yang turun. Sebagai bagian dari sepuluh fakultas yang ada di Unsri, 
Fakultas Teknik Unsri membutuhkan suplai air bersih yang cukup besar untuk keperluan sivitas akademika dan karyawanya.

Berangkat dari fakta yang ada maka Fakultas Teknik Unsri berinisiatif mencari alternatif dengan membangun tiga sumur bor dengan kedalaman ratarata 50-60 meter. Air sumur bor ini diharapkan dapat mencukupi kebutuhan ketika suplai dari unit pengolahan air Unsri mengalami gangguan. Hasil analisis awal terhadap air yang dihasilkan sumur bor FT. Unsri menunjukan ada sebagian parameter yang belum memenuhi persyaratan kualitas antara lain $\mathrm{pH}$, turbidit, dan kandungan bakteri e-coli dan coliform seperti yang telah diatur dalam Permenkes RI/492/Menkes/Per/IV/2010. Untuk itu telah dilakukan penelitian untuk mengolah air sumur bor tersebut sehingga memenuhi syarat air bersih dengan menggunakan kombinasi adsorben dan membran ultrafiltrasi (UF). Dua jenis adsorben yang diujicoba adalah fly-ash dan zeolit.

\subsection{Fly-ash}

Fly-ash merupakan partikulat hasil samping pembakaran batubara pada sebuah coal fired power plant dan biasanya digunakan kembali sebagai raw material pada industri konstruksi, untuk sintesis senyawa geopolimer, carbon nanotube dll. (Xing et al., 2019) dan menjadi topik perhatian peneliti karena banyak digunakan sebagai adsorbent dan filter untuk pengolahan air dan air limbah (Mushtaq dkk, 2019). Fly-ash mempunyai kemampuan untuk mereduksi ion logam berat dari industri tekstil (Shah dkk, 2013). Flyash juga merupakan adsorben yang cukup ekonomis untuk menghilangkan ion ion $\mathrm{Ni}$ (II) and $\mathrm{Cu}$ (II) dari larutan aqueousnya (Sočo dan Kalembkiewic, 2013).

Sebagai salah satu adsorben yang potensial keberadaan fly-ash hasil pembakaran batubara di Indonesia belum dimanfaatkan secara maksimal selain sebagai campuran untuk bahan konstruksi atau pembuatan jalan. Penggunaan fly-ash sebagai campuran dalam pembuatan filter keramik untuk mengolah air rawa menjadi air bersih telah dilakukan oleh Nasir, dkk (2013). Hasil yang diperoleh menunjukkan bahwa membran keramik yang dibuat dari campuran tanah liat dan fly-ash dapat menaikan $\mathrm{pH}$ air rawa menjadi 6,4 - 6,9 dan menurunkan kandungan ion besi dan seng berturut-turut $99 \%$ dan 96\%. Proses pengolahan air asam tambang menggunakan fly-ash yang dikombinasikan dengan membran ultrafiltrasi (UF) dan reverse osmosis (RO) mampu menurunkan total dissolved solid (TDS) dan electrical conductivity (EC) pada air yang dihasilkan. Adsorben fly-ash yang digunakan sebagai pengolahan awal untuk air asam tambang dengan membran UF/RO dapat meningkatkan $\mathrm{pH}$ dari 2,4 - 3,9 menjadi 2,7-4,4 (Nasir, dkk 2016).

\subsection{Zeolit}

Zeolit banyak digunakan untuk berbagai aplikasi, terutama yang diarahkan pada aspek peningkatan efektifitas dan efisiensi proses industri. Karena harganya yang relatif murah dan mempunyai kestabilan termal yang tinggi maka zeolit mempunyai potensi aplikasi yang luas dalam proses pemisahan dan sebagai katalis (Loiola dkk, 2012). Zeolit mempunyai struktur tiga dimensi yang dibangun oleh T04 tetrahedra, dengan atom $\mathrm{T}$ atom dapat berupa atom $\mathrm{Si}^{4+}$ atau $\mathrm{Al}^{3+}$ yang terletak ditengah dari struktur oksigen tetrahedron. Perbandingan $\mathrm{Si}^{4+}$ and $\mathrm{Al}^{3+}$ dalam kerangka zeolit dikenal sebagai rasio mol silika terhadap alumina $\mathrm{SiO}_{2} / \mathrm{Al}_{2} \mathrm{O}_{3}$ atau $\mathrm{Si} / \mathrm{Al}$. Zeolit adalah material kristalin mikroporous dari senyawa aluminosilikat berwujud kerangka terbuka tiga dimensi dari tetrahedral yang membentuk jaringan pori dan rongga sehingga dapat digunakan sebagai adsorben atau penukar ion (Li dkk, 2017, Jiang dkk, 2020).

Beberapa penelitian mengenai pemanfaatan zeolit sebagai adsorben terdapat pada beberapa literatur. Adsorpsi ion logam tembaga (II), khrom (III) dan besi (III) dari air limbah industri grafis menggunakan zeolit menunjukan selektivitas $\mathrm{Fe}>\mathrm{Cr}$ $>\mathrm{Cu}$. Zeolit mampu menurunkan $95,4 \%$ besi, $96,0 \%$ tembaga dan $85,1 \%$ khrom pada suhu $25,0^{\circ} \mathrm{C}$ dan $\mathrm{pH}$ 4,0 (Zanin dkk, 2017). Zeolit juga merupakan adsorben potensial untuk mereduksi ion ion Fe(III), $\mathrm{Cu}$ (II), Mn (II) dan Zn (II) dari air asam tambang (Motsi dkk, 2009). Dalam eksperimen lain, Cheng dkk, 2018 yang meneliti kemampuan adsorpsi rhodamine B oleh Beta zeolit dari larutan aqueous menunjukan bahwa kemampuan adsorpsi zeolit terhadap rhodamine $\mathrm{B}$ tergantung pada rasio $\mathrm{SiO}_{2} / \mathrm{Al}_{2} \mathrm{O}_{3}$ dari zeolit. Kemampuan adsorpsi maksimum terhadap rhodamine $\mathrm{B}$ sebesar $27,97 \mathrm{mg} / \mathrm{g}$ dicapai bila rasio $\mathrm{SiO}_{2} / \mathrm{Al}_{2} \mathrm{O}_{3}=18,4$.

\subsection{Ultrafiltrasi}

Ultrafiltrasi merupakan proses pengolahan air dan air limbah berbasis membran yang aplikasinya cukup luas mulai dari pemisahan emulsi minyak (Zhang, dkk 2005), pengolahan air minum (Xia dkk 2007. Chaturvedi dan Dave, 2012.), untuk mengontrol prekursor trihalomethane (Bergasmo, dkk 2011), klarifikasi jus buah-buahan (Echavarría, dkk 2012), proses electroplating (Malami, dkk 2015) sampai pada pemurnian biodiesel (Gomes, dkk 2015) dll. Saat ini teknologi ultrafiltrasi dikenal sebagai proses yang banyak digunakan untuk menghasilkan air minum karena keunggulannya seperti dapat menghasilkan air yang berkualitas tinggi, kompak, mudah dikontrol dan dirawat dan tidak menghasilkan sludge dalam jumlah besar sehingga banyak dimanfaatkan sebagai alternatif teknik pengolahan air yang aman.

Membran ultrafiltrasi merupakan penghalang fisik yang efisien untuk menurukan kadar padatan 
terlarut dan koloid, bakteri, alga, parasit, dan virus juga untuk mengontrol senyawa prekursor trihalomethane (Bergamasco, dkk 2011). Penelitian lainnya dilakukan oleh Xia, dkk (2007) dalam mengolah air sungai menjadi air minum menggunakan koagulan Poly Aluminum Chloride (PAC) dan membran ultrafiltrasi. Kombinasi PAC dan membran ultrafiltrasi dapat mengurangi chemical oxygen demand (COD) sebanyak 41\%, dissolved organic carbon (DOC) sebanyak 46\%.

Pengolahan air baku berbasis membran dapat dikombinasikan dengan proses adsorpsi menggunakan adsorben. Pengolahan air khususnya untuk keperluan air minum tidak dapat sepenuhnya mengeliminasi ion logam terlarut seperti besi dan mangan (Chaturvedi dan Dave, 2012). Untuk itu perlu dilakukan pengolahan pendahuluan (pretreatment) antara lain dengan menggunakan adsorben.

\section{Metodologi}

\subsection{Bahan dan alat}

Penelitian ini dilakukan di Laboratorium Teknik Separasi dan Purifikasi Fakultas Teknik Universitas Sriwijaya. Material yang digunakan dalam penelitian ini adalah fly-ash dan zeolit dengan ukuran partikel rata rata 20 mesh, membran UF type HM90UF (MWCO 50,000-150,000DA) dengan luas area membran $0,3404 \mathrm{~m}^{2}$, kolom adsorben, tangki air umpan, tangki filtrat, tangki permeat, pompa centrifugal, flow meter, pressure gauge dan alat penunjang lainnya seperti $\mathrm{pH}$ meter. Pengukuran parameter analisis air dilakukan menurut SNI No. 6989.4:2009 untuk ion besi, SNI
6989.5:2009 untuk mangan. SNI 06-2840:1991 untuk nitrat. Metode APHA digunakan untuk bakteri E-coli dan Coliform. Sedangkan untuk pH menggunakan SNI 06-6989.11:2004, kekeruhan SNI 06-6989.25:2005, dan suhu 06-6989.23:2005. Untuk ion logam seperti Hg (AAS-MVU), Ar dan Se menggunakan metode AASHVG.

\subsection{Metode}

Sebanyak $40 \mathrm{~kg}$ fly-ash dihomogenisasi dengan akuades dan diaduk kemudian dipanaskan pada suhu $110{ }^{\circ} \mathrm{C}$ selama 1 jam dan dimasukan dalam kolom adsorben yang terbuat dari fiber. Zeolit dengan ukuran partikel 20 mesh sebanyak $40 \mathrm{~kg}$ diaktivasi dengan $\mathrm{HCl} 0,1 \mathrm{~N}$, dicuci dengan aquades dan dipanaskan selama 2 jam pada suhu $300^{\circ} \mathrm{C}$ dan dimasukan ke dalam kolom adsorben yang terbuat dari fiber.

Air sumur bor ditampung dalam tangki air umpan dan dipompakan ke kolom adsorben dengan laju alir konstan yaitu $5 \mathrm{~L} /$ menit. Filtrat dari kolom adsorbsi adsorpsi diambil setiap 15 menit untuk analisis $\mathrm{pH}$, turbiditas, dan kandungan logam Fe serta Mn. Filtrat dari kolom adsorben ditampung dalam tanki berkapasitas 220L lalu dipompakan ke membran UF dengan laju alir 4, 5, 6 dan 7 L/menit. Permeat dari UF disterilisasi menggunakan sinar UV selama 10 menit dan kemudian diambil sebanyak $200 \mathrm{~mL}$ untuk dianalisis setiap 15 menit. Semua ekperimen dilakukan pada suhu ruang $\left(28{ }^{\circ} \mathrm{C}-30{ }^{\circ} \mathrm{C}\right)$ dengan variasi waktu operasi $(15,30,45,60,75$ dan 90 menit $)$ dan laju alir umpan $(4,5,6$, dan $7 \mathrm{~L} /$ menit $)$.

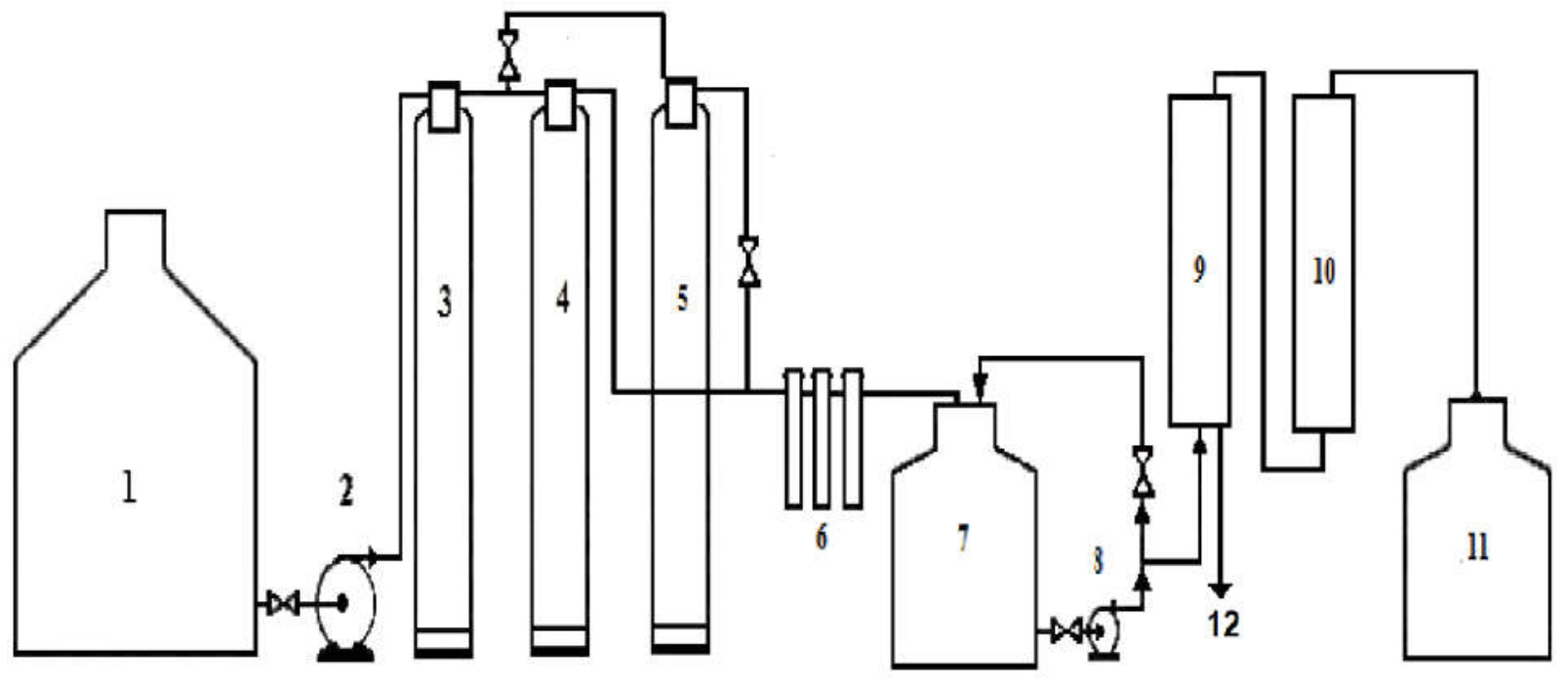

Gambar 1 Skema peralatan

1.Tangki umpan 2. Pompa sentrifugal 3. Sand filter 4. Kolom adsorben Fly-ash 5. Kolom Zeolit 6. Filter Spoon 7. Tangki Filtrat 8. Pompa Sentrifugal 9. Membran Ultrafiltrasi 10. Tabung Lampu Ultraviolet 11. Tangki Permeat 12. Konsentrat)

\section{Hasil dan Pembahasan}

\subsection{Analisis sampel}

Sampel yang digunakan air yang berasal dari sumur bor yang berlokasi di Fakultas Teknik Universitas Sriwijaya Kampus Indralaya dengan hasil analisis sampel seperti tertera pada Tabel 1. Beberapa parameter menunjukan nilai yang melampaui standar yaitu turbiditi, keasaman $(\mathrm{pH})$, dan kandungan bakteri e-coli dan coliform. Untuk itu penelitian ini difokuskan pada bagaimana metoda meningkatkan 
kualitas air hasil pengolahan dari aspek turbiditi, keasaman dan penghilangan bakteri e-coli dan coliform.

Tabel 1. Hasil Analisis Sampel

\begin{tabular}{|c|c|c|c|c|}
\hline No. & Parameter & Satuan & Standard & Hasil \\
\hline 1. & Bau & - & Tidakberbau & Tidak berbau \\
\hline 2. & Rasa & - & Tidak berasa & Tidak berasa \\
\hline 3. & TDS & $\mathrm{mg} / \mathrm{L}$ & 500 & 29 \\
\hline 4. & Kekeruhan & NTU & 5 & 38,41 \\
\hline 5. & Suhu & ${ }^{\circ} \mathrm{C}$ & Suhu udara \pm 3 & 25,1 \\
\hline 6. & Warna & TCU & 15 & 20 \\
\hline 7. & $\mathrm{Hg}$ & $\mathrm{mg} / \mathrm{L}$ & 0,001 & $<0,0001$ \\
\hline 8. & As & $\mathrm{mg} / \mathrm{L}$ & 0,01 & $<0,0009$ \\
\hline 9. & $\mathrm{Fe}$ & $\mathrm{mg} / \mathrm{L}$ & 0,3 & 0,08 \\
\hline 10. & $\mathrm{~F}$ & $\mathrm{mg} / \mathrm{L}$ & 1,5 & 0,09 \\
\hline 11. & $\mathrm{Cd}$ & $\mathrm{mg} / \mathrm{L}$ & 0,003 & $<0,0015$ \\
\hline 12. & $\mathrm{CaCO}_{3}$ & $\mathrm{mg} / \mathrm{L}$ & 500 & 168 \\
\hline 13. & Mn & $\mathrm{mg} / \mathrm{L}$ & 0,4 & 0,03 \\
\hline 14. & Nitrat $\left(\mathrm{NO}_{3}\right)$ & $\mathrm{mg} / \mathrm{L}$ & 150 & 4,01 \\
\hline 15. & Nitrat $\left(\mathrm{NO}_{2}\right)$ & $\mathrm{mg} / \mathrm{L}$ & 13 & 0,013 \\
\hline 16. & $\mathrm{pH}$ & - & $6,5-8,5$ & 5,42 \\
\hline 17. & $\mathrm{Se}$ & $\mathrm{mg} / \mathrm{L}$ & 0,01 & $<0,0012$ \\
\hline 18. & $\mathrm{Zn}$ & $\mathrm{mg} / \mathrm{L}$ & 3 & 0,02 \\
\hline 19. & $\mathrm{CN}$ & $\mathrm{mg} / \mathrm{L}$ & 0,07 & 0,008 \\
\hline 20. & $\mathrm{SO}_{4}$ & $\mathrm{mg} / \mathrm{L}$ & 250 & 18,1 \\
\hline 21. & $\mathrm{~Pb}$ & $\mathrm{mg} / \mathrm{L}$ & 0,01 & $<0,003$ \\
\hline \multirow[t]{2}{*}{22.} & Organik & & & \\
\hline & $\left(\mathrm{KmnO}_{4}\right)$ & $\mathrm{mg} / \mathrm{L}$ & 10 & 3,31 \\
\hline 23. & Detergen & $\mathrm{mg} / \mathrm{L}$ & 0,05 & $<0,0001$ \\
\hline 24. & E.Coli & per $100 \mathrm{ml}$ & & \\
\hline \multirow{2}{*}{25.} & Koliform & $\begin{array}{l}\text { sampel } \\
\text { per } 100 \mathrm{ml}\end{array}$ & 0 & 2,2 \\
\hline & & sampel & 0 & 2,2 \\
\hline
\end{tabular}

\subsection{Pengaruh waktu terhadap $\mathrm{pH}$}

Analisis $\mathrm{pH}$ air sumur bor yang telah diproses pada kolom sand filter dan kolom adsorben fly-ash maupun zeolit dan kombinasinya dengan Ulftrafiltrasi ditampilkan pada Gambar 2. Umumnya kenaikan $\mathrm{pH}$ dimulai pada waktu operasi 15 menit pertama dan akan stabil pada 30 menit berikutnya. Pada laju alir umpan $4 \mathrm{~L} /$ menit filtrat yang diperoleh mempunyai pH 8,1 bila digunakan adsorben fly-ash dan cenderung stabil setelah waktu operasi 30 menit. Hal yang sama dijumpai untuk zeolit yang mampu menaikan $\mathrm{pH}$ filtrat menjadi sekitar 7,3 maupun kombinasi flyash/UF menjadi 8,05 dan kombinasi zeolite/UF menjadi 7,23. Secara keseluruhan waktu operasi tidak berpengaruh secara signifikan terhadap $\mathrm{pH}$ yang dihasilkan. Kenaikan nilai $\mathrm{pH}$ pada berbagai variasi laju alir kolom sand filter dan kolom adsorpsi dibandingkan dengan nilai $\mathrm{pH}$ sampel awal menunjukkan bahwa baik fly-ash dan zeolit atau kombinasi fly-ash/UF dan zeolite/UF dapat dengan cepat meningkatkan $\mathrm{pH}$ air sumur bor.

Kenaikan pH terjadi karena fly-ash memiliki kandungan mineral seperti $\mathrm{CaO}$ yang berfungsi sebagai senyawa alkali pembentuk suasana basa sehingga dapat meningkatkan pH air (Ge, dkk 2018). Filtrat yang dihasilkan cenderung bersifat basa $(\mathrm{pH}$ antara 8,0-8,2). Hal ini terjadi karena semakin kecil laju alir dan makin lama waktu operasi maka kontak antara air dan fly-ash semakin intensif. Hal ini akan berpengaruh terhadap keasaman filtrat sehingga sampel yang awalnya bersifat asam akan dinetralisir oleh senyawa $\mathrm{CaO}$ dalam fly-ash. Ketika waktu kontak sampel yang cukup singkat dalam kolom adsorpsi maka filtrat cenderung bersifat basa karena difusi ion dari sampel pada adsorben belum maksimal.



Gambar 2 Pengaruh waktu terhadap pH filtrat pada laju alir umpan UF sebesar 4L/menit

Penggunaan zeolit sebagai adsorben mampu menaikan pH dari 5,43 menjadi 7,1 sampai 7,3. Hasil ini menunjukkan bahwa zeolit yang memiliki struktur berongga memiliki kapasitas tukar kation yang tinggi sehingga dapat mengadsorp dan menukar kationkation yang terlarut dalam air umpan. Selain itu molekul air dapat dihilangkan dari struktur zeolit sehingga membentuk void space yang dapat ditempati oleh spesies lain yang cocok ukuran, bentuk dan polaritasnya sehingga zeolit juga dapat bertindak sebagai molecular sieve (Li dkk, 2017; Jiang dkk, 2020). Variasi perbedaan laju alir dan waktu operasi juga tidak menunjukkan perbedaan signifikan pada keasaman filtrat hasil adsorpsi setelah 30 menit waktu operasi. Filtrat yang diperoleh dengan metode adsorpsi menggunakan zeolit menunjukan pH yang lebih baik dibandingkan dengan hanya menggunakan filter keramik yang terbuat dari campuran tanah liat dan zeolit yaitu berkisar antara 6,90-6,96 (Nasir, 2013).

\subsection{Pengaruh waktu terhadap turbiditi}

Turbiditi merupakan salah satu parameter kualitas air dan air limbah yang sangat tergantung pada padatan tersuspensi yang ada dalam air atau air limbah. Turbiditi larutan relatif lebih mudah diukur dibandingkan COD and BOD (Castaño dan Higuita, 2016). Dalam aplikasi membran, air dengan turbiditas tinggi dapat menyebabkan turunnya fluks membran (Chen dkk, 2019).

Pengaruh waktu operasi terhadap persentase penurunan turbiditi ditampilkan pada Gambar 2 . 


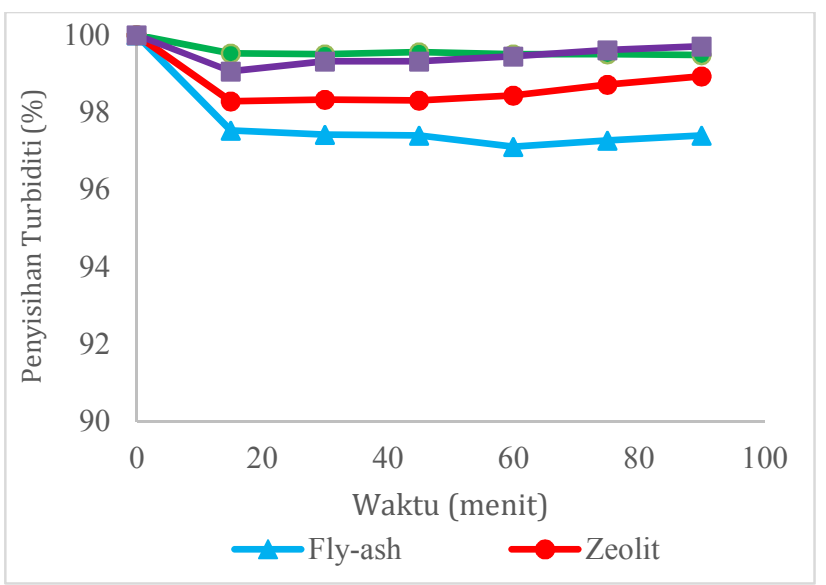

Gambar 3 Pengaruh waktu terhadap persentase penyisihan turbiditi

Penurunan turbiditi filtrat dari kolom adsorben fly-ash $(97,53 \%)$ sedikit lebih rendah daripada kolom adsorben zeolit $(98,28 \%)$ pada berbagai rentang waktu operasi. Hal ini menunjukan bahwa kemampuan adsorpsi zeolit lebih baik dari fly-ash. Semakin lama waktu operasi dan semakin tinggi laju alir umpan maka semakin tinggi persentase penurunan turbiditi. Walaupun demikian konsentrasi solut yang tinggi pada permukaan adsorben akan membuat adsorben menjadi jenuh karena pori adsorben yang tertutupi oleh solut dan juga ion-ion terutama ion logam dalam air umpan yang ukuran molekulnya lebih besar dari pori-pori adsorben.

Bila penggunaan adsorben fly-ash atau zeolit dikombinasikan dengan ultrafiltrasi maka persentase penurunan turbiti akan meningkat lebih dari 99\%. Hal ini karena sebagian besar solut telah terpisah pada kolom adsorpsi. Namun demikian menurut Inga Hilbrandt dkk (2019) kinerja kombinasi adsorpsi dan ultrafiltrasi sangat tergantung pada komposisi air umpan, konsentrasi awal polutan dan persentase penyisihan yang diinginkan.

Penggunaan adsorben sebelum proses ultrafiltrasi mengakibatkan konsentrasi solut pada air umpan menuju membran akan berkurang dan konsentrasi solut pada fasa bulk di permukaan membran maupun pada permeat akan menurun. Sebagai konsekuensinya maka laju alir permeat yang diperoleh akan semakin tinggi. Dengan demikian akan meminimalisir kemungkinan terjadinya fouling karena penumpukan (build-up) solut pada dinding membran. Hal ini sesuai dengan teori polarisasi konsentrasi yang menyatakan terjadinya akumulasi reversibel dari molekul padatan pada permukaan membran karena proses konveksi dan difusi. Dalam proses membran semua komponen umpan yang tertolak oleh membran akan ditransportasikan ke permukaan membran pada fasa bulk dengan cara konveksi. Jika pola aliran dalam system membran laminar maka proses yang terjadi cenderung pada difusi (Cui dan Muralidhara, 2010).

Penurunan turbiditi dengan menggunakan adsorben fly-ash/UF maupun kombinasi Zeolit/UF menunjukkan hasil yang hampir sama dengan yang diperoleh lebih baik dibandingkan dengan hasil yang diperoleh peneliti sebelumnya yang menggunakan kombinasi PAC dengan ultrafiltrasi (Xia dkk, 2007). Kombinasi Fly ash/UF maupun Zeolit/UF mampu menurunkan turbidty berturut-turut $99.48 \%$ dan 99.71\%. Xia dkk, mendapatkan penurunan turbidity dari air sungai yang diolah dengan kombinasi Poly Aluminum Chlorida (PAC) dan Ultrafiltrasi sebesar 99\%. Hasil yang diperoleh juga lebih baik dari hasil simulasi Racar dkk 2019 dengan menggunakan kombinasi koagulasi, sand filter-ultrafiltrasi yaitu penyisihan turbiditi sebesar $96 \%$.

\subsection{Penurunan kadar nitrat, besi dan mangan}

Senyawa nitrat, besi, dan mangan merupakan senyawa yang sangat berpengaruh terhadap kualitas air bersih dan air minum. Nitrat dapat direduksi menjadi nitrit yang berbahaya bagi kesehatan karena dapat mengoksidasi ion fero menjadi feri dalam haemoglobin sehingga darah mengalami kelainan karena jumlah methemoglobin yang berlebihan (methemoglobinemia) yang mengakibatkan darah menjadi kekurangan oksigen (David, dkk 2018). Ion besi dan mangan terlarut dapat mempengaruhi sifatsifat organoleptik air.

Nitrat merupakan senyawa yang kelarutannya tinggi dalam air dan merupakan kontaminan dalam air tanah yang dapat berpengaruh terhadap suplai air minum, berbahaya bagi kesehatan dan juga memicu eutrofikasi (Bhatnagar dan Sillanpää, 2011). Gambar 4 menampilkan pengaruh berbagai macam proses terhadap kandungan nitrat. Fly-ash dan kombinasi flyash dengan ultrafiltrasi tidak menunjukan perubahan yang signifikan dibandingkan kadar nitrat pada sampel awal. Sementara pengolahan air umpan menggunakan zeolit dan kombinasi zeolit dengan ultrafiltrasi menunjukan kadar nitrat yang hampir sama dalam filtrat dan permeat yang dihasilkan. Hal ini diduga karena waktu kontak antara zeolit dengan sampel yang singkat yaitu hanya 90 menit. Walaupun demikian nilai yang diperoleh masih di bawah baku mutu yang diizinkan. Kadar nitrat dalam air khususnya air tanah seringkali fluktuatif tergantung musim dan intensitas pengairan dan suhu (Gao, dkk 2012). Kadar nitrat seringkali meningkat ketika musim hujan dan menurun saat musim kemarau. Menurut Bhatnagar dan Sillanpää (2011) zeolit hanya cocok untuk mengadsorp amonium dibandingkan nitrat, kecuali dilakukan modifikasi surfaktan zeolit menggunakan material lain seperti chitosan (Mažeikiene, dkk 2008) atau dengan polydopamine (Orimi dkk, 2018). 


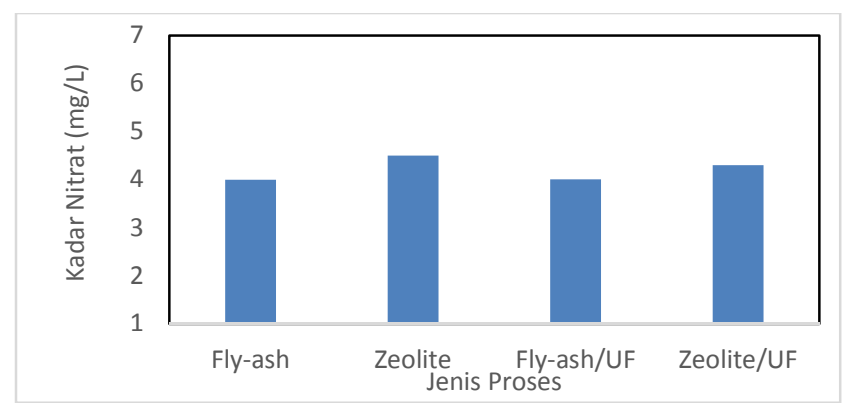

Gambar 4. Kadar nitrat dalam filtrat hasil proses menggunakan adsorben dan kombinasinya dengan ultrafiltrasi

Gambar 5 menampilkan perbedaan kemampuan adsorpsi ion $\mathrm{Fe}$ dan $\mathrm{Mn}$ oleh fly-ash, zeolit, dan kombinasi antara fly-ash/UF serta zeolit/UF. Kemampuan adsorpsi fly-ash lebih tinggi untuk logam besi dibandingkan mangan hal ini karena ion besi mudah mengendap pada $\mathrm{pH}$ sekitar 7 sedangkan ion mangan akan lebih mudah mengendap dalam bentuk mangan hidroksida pada suasana basa $(\mathrm{pH}>=8)$ sehingga ion besi yang mengendap akan teradsorp pada permukaan adsorben. Zeolit mempunyai performa yang lebih baik dalam mengadsorpsi ion besi dan mangan karena kemampuannya dalam mempertukarkan ion dan sifat molecular sievenya (Wang dan Peng, 2010). Namun untuk mengadsorpsi nitrat diperlukan modifikasi struktur permukaan zeolit dengan cara melapisi permukaan dengan chitosan atau polydopamin (Mažeikiene dkk, 2008, Bhatnagar dan Sillanpää. 2011, Orimi dkk, 2018 bahkan studi yang pernah dilakukan bahwa zeolit yang dilapisi dengan seng oksida dapat mereduksi jumlah bakteri e-coli dalam air (Wang dkk, 2018).

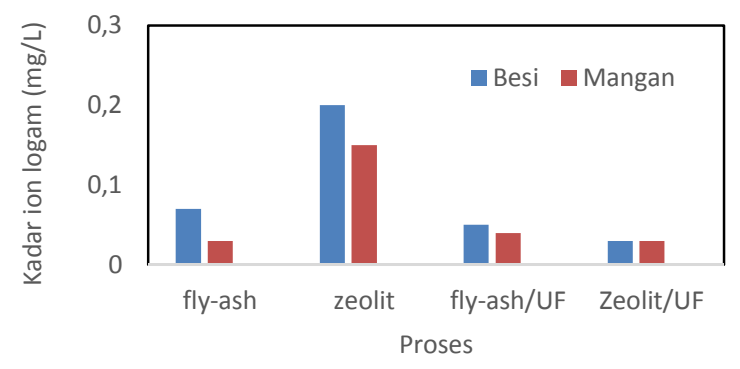

Gambar 5 Kadar besi dan mangan dalam filtrat hasil proses menggunakan adsorben dan kombinasinya dengan ultrafiltrasi

Namun demikian kemampuan zeolit dalam menyerap ion mangan akan menjadi dua kali lipat bila berada dalam suasana basa (Ates dan Gökçen, 2016).

Proses filtrasi menggunakan zeolit/UF menunjukkan penurunan ion besi sekitar 37,5\%, sedangkan mangan menurun sekitar $72,5 \%$. Hal ini menunjukan bahwa penggunaan zeolit sangat efektif untuk menurunkan kandungan mangan yang terlarut di dalam air umpan.

\subsection{Bakteri E-coli dan Coliform}

(C) 2020, Program Studi Ilmu Lingkungan Sekolah Pascasarjana UNDIP
Bakteri E-coli dan Coliform merupakan salah satu parameter yang diatur dalam Permenkes/No.492/ Menkes/Per/IV/2010 yang mensyaratkan kadar maksimal 0 per $100 \mathrm{ml}$ sampel. Kandungan bakteri ecoli dan coliform pada sampel awal adalah 2 per 100 $\mathrm{ml}$ sampel. Pengolahan awal menggunakan sand filter dan adsorben fly-ash maupun zeolit tidak dapat menurunkan kandungan bakteri e-coli dan coliform dari air umpan karena secara teoritis baik fly-ash maupun zeolit merupakan material berpori dengan ukuran pori yang jauh lebih besar dari ukuran bakteri maupun virus. Membran ultrafiltrasi dapat menghilangkan kandungan bakteri e-coli dan coliform sampai 100\%. Menurut Polyakov dan Zydney (2013) dalam proses membran ketika ukuran partikel solut yang ada dalam larutan umpan lebih kecil dari diameter hidraulik pori membran maka solut dapat memasuki pori dan lolos ke permeat atau menempel pada dinding pori. Hal ini dikenal sebagai pore restriction. Karena membran ultrafiltrasi memiliki diameter hidrualik rata rata yang lebih kecil dibandingkan bakteri dan virus. sehingga dapat menolak bakteri juga virus. Selain itu penurunan kandungan bakteri e-coli dan coliform juga dibantu oleh proses desinfeksi menggunakan sinar Ultra Violet (UV) yang juga efektif menghilangkan mikroorganisme maupun zat organik (Jin, dkk 2018).

\section{Kesimpulan}

Dari hasil penelitian ini dapat disimpulkan bahwa kombinasi fly-ash/UF dapat meningkatkan $\mathrm{pH}$ air sumur bor dari 5,43 menjadi 7,0-8,1 dengan efisiensi penurunan turbiditi mencapai 99,48\%. Kombinasi zeolite/UF mampu menaikan $\mathrm{pH}$ dari 5,43 menjadi 7,1 sampai 7,3 dan menurunkan turbiditi sebesar 99,71\% dan kedua metode ini dapat menurunkan logam besi dan mangan yang terkandung di dalam air sumur bor. Kombinasi pengolahan air sumur bor menggunakan zeolit/UF lebih baik daripada kombinasi fly-ash/UF ditinjau dari berbagai parameter air bersih seperti $\mathrm{pH}$ dan turbiditi. Untuk itu penggunaan adsorben sebagai pretreatment sebelum proses ultrafiltrasi akan dapat membantu dalam menyisihkan ion-ion logam besi dan mangan dan sekaligus mempersiapkan umpan yang memenuhi kriteria membran ultrafiltrasi.

\section{DAFTAR PUSTAKA}

Ates, A., dan G. Akgül. 2016. Modification of natural zeolite with $\mathrm{NaOH}$ for removal of manganese in drinking water. Powder Technology. 287:285-291.

Bergamasco. R., L. C. K. Moraes, M. F. Vieira, M. R. F. Klen, dan A. M. S. Viera. 2011. Performance of a coagulationultrafiltration hybrid process for water supply treatment. Chemical Engineering Journal. 166 (2): 483-498.

Bhatnagar. A., M. Sillanpää. 2011. Review: A review of emerging adsorbents for nitrate removal from water. Chemical Engineering Journal.168:493-504. 
Castaño, J. A., dan J. C. Higuita. 2016. Using turbidity for designing water networks, Journal of Environmental Management. 172: 129-135

Chaturvedi, S., dan P.N. Dave. 2012. Removal of iron for safe drinking water. Desalination. 303:1-11.

Chen, Y.Y., W. Xu, H. Zhu, D. Wei, F. He, D. Wang, B. Du, dan Q. Wei. 2019, Effect of turbidity on micropollutant removal and membrane fouling by MIEX/ultrafiltration hybrid process, Chemosphere. 216: 488-498

Cheng, Z. L., Y. Li, dan Z. Liu. 2018. Study on adsorption of rhodamine $\mathrm{B}$ onto Beta zeolites by tuning $\mathrm{SiO}_{2} / \mathrm{Al}_{2} \mathrm{O}_{3}$ ratio. Ecotoxicology and Environmental Safety. 148:585-592.

Cui, Z. F., dan H.S. Muralidhara (2010). Membrane Technology: A Practical Guide to Membrane Technology and Applications in Food and Bioprocessing. Butterworth-Heinemann.

David. S. R., N.S. Sawal, M. N. S. Hamzah, dan R. Rajabalaya. 2018. The blood blues: A review on methemoglobinemia. Journal of Pharmacology \& Pharmacotheraupetics. 9 (1):1-5.

Echavarría, A.P., V. Falguera, C. Torras, C. Berdún, C. Pagána, dan J. Ibarz. 2012, LWT- Food Science and Technology. 46: 189-195.

Gao. Y., G. Yu, C Luo, dan P. Zhou. 2012. Groundwater Nitrogen Pollution and Assessment of Its Health Risks: A Case Study of a Typical Village in Rural-Urban Continuum, China. PLoS ONE 7(4).

Ge, J. C., S. K. Yoon dan N. J. Choi. 2018. Review: Application of Fly Ash as an Adsorbent for Removal of Air and Water Pollutans. Applied Sciences. 8 (1116): 3-24.

Gomes, M.C.C., P. A. Arroyo, dan M. C. Pereira. 2015. Influence of oil quality on biodiesel purification by ultrafiltration. Journal of Membrane Science. 496: 242-249.

Jiang, N., M. Erdős, O. A. Moultos, R. Shang, T.J.H. Vlugt, S. G.J. Heijman dan L. C. Rietveld. 2020. The adsorption mechanisms of organic micropollutants on high-silica zeolites causing S-shaped adsorption isotherms: An experimental and Monte Carlo simulation study. Chemical Engineering Journal. 289:123968

Jin, Y., H. Lee. M. Zhan dan S. Hong., 2018. UV radiation pretreatment for reverse osmosis (RO) process in ultrapure water (UPW) production. Desalination. 439:138-146.

Li, Y., L. Li. dan J. Yu. 2017. Review : Applications of Zeolites in Sustainable Chemistry. Chem. 3:928-949.

Loiola, A.R., J. C. R. A. Andrade, J. M. Sasaki, dan R.D. da Silva. 2012. Structural analysis of zeolite NaA synthesized by a cost-effective hydrothermal method using kaolin and its use as water softener. Journal of Colloid and Interface Science. 367 (1): 34-39.

M. Racar, D. Dolar, M. Farkaš, N. Milčić, A. Špehar, K. Košutić, 2019. Rendering plant wastewater reclamation by coagulation, sand filtration, and ultrafiltration Chemosphere. 227: 207-215.

Malami, S., E. Katsou, T. Kosanovic, dan K. J. Harambolaus. 2012. Combined Adsorption and Ultrafiltration Processes Employed for the Removal of Pollutants from Metal Plating Wastewater. Journal Separation Science and Technology. 47 (7): 983-986.
Mažeikiene, A., M. Valentukevičiene, M. Rimeika, A.B. Matuzevičius dan R. Dauknys. 2008. Removal of nitrates and ammonium ions from water using natural sorbent zeolite (clinoptilolite), Journal of Environmental Engineering and Landscape Management. 16: 38-44.

Motsi, T., N. A. Rowson, dan M. J. H. Simmons. 2009. Adsorption of heavy metals from acid mine drainage by natural zeolite. International Journal of Mineral Processing. 92: 42-48.

Mushtaq, F., M. Zahid, I. A. Bhatti, S. Nasir, dan T. Hussain. 2019. Possible applications of coal fly ash in wastewater treatment, Journal of Environmental Management. 240:27-46.

Nasir, S., 2013. Treatment of Domestic Water Using Ceramic Filter from Natural Clay and Fly-ash. Journal of Engineering Studies and Research. 19: 71-75.

Nasir, S., E. Ibrahim., dan A.T. Arief. 2016, Design and Experimental Testing of Small-scale of Acid Mine Drainage Treatment Plant. Journal of Materials and Environmental Science. 7:2912-2918.

Orimi, R. G, B. Mirzayi, A. Nematollahzadeh, A. Tardast. 2018. Competitive adsorption of nitrate in fixed-bed column packed with bio-inspired polydopamine coated zeolite. Journal of Environmental Chemical Engineering. $6: 2232-2240$

Polyakov, Y. S., dan A. L. Zydney. 2013. Ultrafiltration membrane performance: Effects of pore blockage/constriction. Journal of Membrane Science. 34: 106-120.

Sočo., E. dan J. Kalembkiewicz. 2013. Adsorption of nickel (II) and copper (II) ions from aqueous solution by coal fly ash. Journal of Environmental Chemical Engineering. 1: 581-588.

Wang, L. L., W. Wu, X. Xie, H. Chen, J. Lin, dan D. D. Dionysiou. 2018. Removing Escherichia coli from water using zinc oxide-coated zeolite. Water Research.141: 145-151.

Wang, S., dan Y. Peng. 2010. Review: Natural zeolites as effective adsorbents in water and wastewater treatment. Chemical Engineering Journal.156:11-24.

Xia, S., Y. Liu. X. Li dan J. Yao. 2007. Drinking Water Production by Ultrafiltration of Songhuajiang River with PAC Adsorption. Journal of Environmental Sciences. 19: 536-539.

Xing, Y., F. Guo, M. Xu, X. Gui, H. Li, G. Li, Y. Xia, dan H. Han. 2019. Separation of unburned carbon from coal fly ash: A review. Powder Technology. 353:372-384.

Yang, H., J. Cao, Z. Wang, H. Chen, dan X. Gong. 2014, Discovery of impurities existing state in carbide slag by chemical dissociation, International Journal of Mineral Processing. 130: 66-73.

Zanin, E., J. Scapinello, M. Oliveira, C. L. Rambo, F. Franscescon, L. Freitas, J. M. M. de Mello, M. A. Fiori, J. V. Oliveira, dan J. D. Magro. 2017. Adsorption of heavy metals from wastewater graphic industry using clinoptilolite zeolite as adsorbent. Process Safety and Environmental Protection. 105: 194-200.

Zhang, J.C., Y.H. Wang, L. F. Song, J. Y. Hu, S. L. Ong, W. J. Ng, L.Y. Lee. 2005. Feasibility investigation of refinery wastewater treatment by combination of PACs and coagulant with ultrafiltration. Desalination. 174 (3): 247-256. 